\title{
WORKING THE SYSTEM: \\ Should Patients in NeEd Of AN ORgan Transplant \\ Be Able to Join Multiple Waitlists?
}

\author{
Chad J. Wilson ${ }^{*}$
}

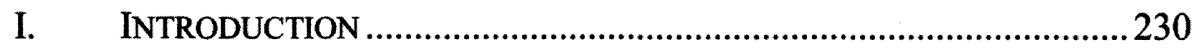

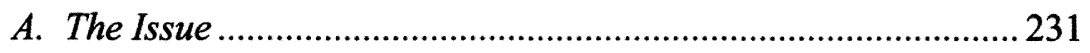

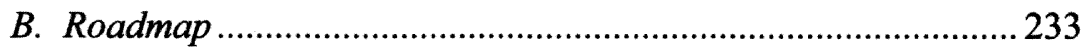

II. THE HISTORY AND FUNCTIONING OF THE ORGAN TRANSPLANT

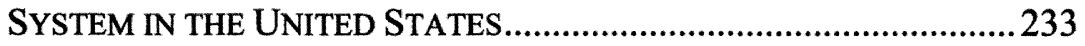

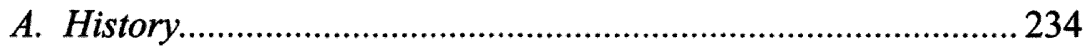

B. Current Structure and Functioning of the Organ

Transplantation Process.......................................................... 238

1. The Relationship Between Transplant Centers and Organ Procurement Organizations ..................................... 238

2. UNOS Policy for Organ Allocation ....................................... 239

3. Not All Organ Procurement Organizations Are

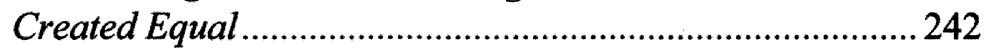

4. Not All Transplant Centers Are Created Equal ...................2243

5. UNOS Allows Multiple Listings ........................................... 245

III. PATIENTS IN NEED OF AN ORGAN TRANSPLANT SHOULD

CONTINUE TO BE AlLOWED to Place THEMSELVES ON THE

WAIT LIST AT MULTIPLE TRANSPLANT CENTERS............................246

A. Arguments in Favor of Allowing Patients to Place

Themselves on Multiple Waitlists ................................................ 246

1. Patient Autonomy in Treatment Choices ............................. 246

2. Multiple Wait Listing May Potentially Help Patients Who Are Only on a Single List ............................................ 249

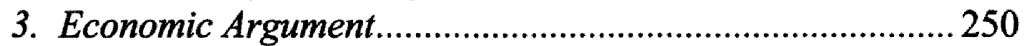

4. Enforcing Wait Time Equity Frustrates the Two Goals of HHS in Relation to Organ Transplantation...................... 251

a. Minimal waste of organs ................................................251

b. Maximum survival rates...............................................252

B. Arguments for Disallowing Patients to Place Themselves

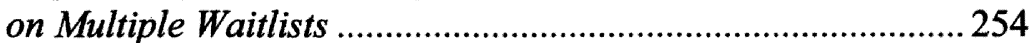

1. Public View of the Fairness of the System Affects the

Likelihood of Donation. 254

2. Allowing Multiple Listings "Pushes" a Truly Local Patient Down the List Further and Forces Him to Wait

* J.D. Candidate, 2011, Indiana University School of Law - Indianapolis; Doctor of Physical Therapy, 2005, Indiana University School of Medicine; B.A., 2002, Indiana University. 


\section{INTRODUCTION}

In October of 2003, Steve Jobs, the cofounder and CEO of the wellknown computer and technology company Apple, ${ }^{1}$ underwent a routine abdominal scan. ${ }^{2}$ During this scan, doctors found an abdominal tumor; ${ }^{3}$ a biopsy of the tumor revealed that Jobs had pancreatic cancer. ${ }^{4}$ While pancreatic cancer is very often a death sentence, ${ }^{5}$ Jobs was lucky. Doctors found that he had a rare, more treatable form and that successful surgical removal of the tumor would most likely lead to at least ten more years of life. ${ }^{6}$ After going against his doctors' orders by pursuing alternative treatments for nine months, Jobs underwent surgery to remove the tumor from his pancreas in July 2004 at Stanford University Medical Center in Palo Alto, California. ${ }^{7}$ A few years following his surgery, Jobs had complications and needed a liver transplant. ${ }^{8} \mathrm{He}$ underwent this procedure in April of 2009. ${ }^{9}$ The fact that a well-known businessman or celebrity received a liver transplant is not noteworthy in itself. In this case, however, Jobs' transplant surgery took place at a hospital located in Tennessee, approximately 2,000 miles from his home in Northern California. ${ }^{10}$

Media coverage often undermines the American public's trust in the organ transplant system. ${ }^{11}$ The American public often assumes that celebrities or other well-known people get preferential treatment when waiting for an organ transplant. ${ }^{12}$ In 1995, professional baseball legend Mickey Mantle received a liver transplant only forty-eight hours after being placed on the

1. Ray Hainer, Did Steve Jobs' Money Buy Him a Faster Liver Transplant?, CNN HEALTH (June 24, 2009), http://www.cnn.com/2009/HEALTH/06/24/ liver.transplant .priority.lists/index.html.

2. Peter Elkind, The Trouble with Steve Jobs, CNN Money (Mar. 5, 2008), http://money.cnn.com/2008/03/02/news/companies/elkind jobs.fortune/index.htm.

3. Id.

4. Id.

5. Pancreatic Cancer Life Expectancy, PANCREATIC CANCER TrEatment, http://www.pancreaticcancertreatment.net/pancreatic-cancer-life-expectancy.html (last visited Mar. 6, 2010).

6. Elkind, supra note 2.

7. Id.

8. Hainer, supra note 1.

9. Id. While the controversy surrounds Jobs' liver transplant, his previous health concerns with pancreatic cancer are pertinent background information because concurrent or past illnesses are a consideration in determining organ allocation.

10. Id.

11. Gail L. Daubert, Notes \& Comment, Politics, Policies, and Problems with Organ Transplantation: Government Regulation Needed to Ration Organs Equitably, 50 ADMIN. L. REV. 459, 477-78 (1998).

12. Hainer, supra note 1. 
waitlist. ${ }^{13}$ Mantle then died two months later. ${ }^{14}$ In Mantle's case, media attention was great, and the public, along with numerous medical ethicists, debated whether he should have even received the transplant. ${ }^{15}$ Cases such as this one may lead the public to view the organ transplant system as unfair and inequitable. This may lead to a decrease in the number of people who are willing to donate their organs for transplantation to a system that is already short on donors. ${ }^{16}$ Media coverage of Steve Jobs' liver transplant may have the same effect on potential donors.

In the current system, patients with better resources and a better understanding of how the system functions may be able to use this information to improve their likelihood of receiving an organ transplant. ${ }^{17}$ The median wait time for a liver between 2002 and 2007 varied widely between various Organ Procurement Organizations (OPOs); the national average was just over one year, ${ }^{18}$ while some OPOs wait time was as high as three years. ${ }^{19}$ However, the OPO from which Steve Jobs received his liver for transplant had a median wait of just over four months, ${ }^{20}$ while the median wait time before liver transplant for patients between July 1, 2003 and December 31, 2008 at the University of California at Los Angeles Medical Center (a hospital performing liver transplants in Jobs' home state of California) was 25.6 months. $^{21}$

\section{A. The Issue}

While some might assume that Jobs received preferential treatment due to his financial and celebrity status, it is more likely that he placed himself on the waiting lists at multiple transplant centers. ${ }^{22}$ The United Network for Organ Sharing ("UNOS") conducts periodic audits of transplant centers to ensure that candidates are not given preferential treatment over others on the list for nonmedical reasons. ${ }^{23}$ Some patients receive an organ

13. Daubert, supra note 11, at 478; see also Hainer, supra note 1.

14. Daubert, supra note 11, at 478.

15. Id.

16. Id.; see also David Orentlicher, Mary ANNe Bobinski \& MARK A. Hall, Bioethics AND PUBlic Health LAW 405 (2nd ed. 2008).

17. Hainer, supra note 1.

18. Id.; see also National Report for Selected Organ, Liver, Table 6: Time to Transplant for Waitlist Patient, SCIENTIFIC REGISTRY OF TRANSPLANT RECIPIENTS ("SRTR"), $\mathrm{http} / / / \mathrm{www}$.ustransplant.org/csr/current/nationalViewer.aspx?o=LI\&t=06 (last updated July 13,2010 ) (stating that the national median time to liver transplant between July 1, 2004 and June 30, 2009 was 10.9 months, based on data available as of March 30, 2010).

19. Hainer, supra note 1.

20. Id.

21. SRTR, Program and Organ Procurement Organization Specific Reports: UNIVERSITY OF CALIFORNIA AT LOS ANGELES MEDICAL CENTER, LIVER 13 (2009), available at http://www.ustransplant.org/csr/archives/200906/CAUCTX1LI200906.PDF.

22. Hainer, supra note 1.

23. Id. 
for transplantation more quickly than others do because they are "standing in more lines" by placing themselves on the waiting list at multiple transplant centers. $^{24}$ UNOS is fully aware of this practice and expressly allows patients to list themselves at multiple transplant centers. ${ }^{25}$ Further, UNOS allows these listings to be performed at centers located in different geographical locations that are served by different OPOs. ${ }^{26}$ This rule allows a patient like Steve Jobs to potentially decrease the time they spend waiting to get a transplant.

Many patients, however, are unable to be listed at multiple transplant centers due to cost. ${ }^{27}$ In fact, many patients cannot afford the costs associated with transplantation when listed at just a single transplant center. ${ }^{28}$ The current estimated cost of a liver transplant is $\$ 519,600 .^{29}$ This cost prohibits approximately one-third of Americans from obtaining the transplant they need due to insufficient insurance, or a total lack thereof. ${ }^{30}$ Nevertheless, while many patients are hindered by the financial requirements of transplantation, those with large financial assets, like Jobs, are able to use the assets to their advantage. To be evaluated at multiple centers, one must have the financial and physical resources to travel around the country. ${ }^{31}$ The monetary requirement includes the ability to pay all the costs associated with multiple evaluations, as many insurance plans do not cover the cost of examination and evaluation at more than one transplant center. ${ }^{32}$ Further, one must have the financial means to travel to any transplant center across the country at a moment's notice when the needed organ becomes available. Lastly, at some transplant centers the ability to pay for a transplant is a prerequisite to being placed on the wait list. ${ }^{33}$ Because Steve Jobs' estimated worth is approximately twenty-two billion dollars, ${ }^{34}$ the financial and travel issues were not constraining factors, allowing him to take advantage of the fact that UNOS does not prohibit patients from listing themselves on multiple waiting lists around the country. ${ }^{35}$ Most likely, because of this practice,

24. Id.

25. UNOS, 3.2: Organ Distribution, UNOS Patient Waiting List, HEALTH RES. \& SERV. ADMIN., http://optn.transplant.hrsa.gov/PoliciesandBylaws2/policies/pdfs/policy_4.pdf (last updated Nov. 9, 2010) [hereinafter UNOS 3.2] ("Candidates may be waitlisted at multiple transplant centers. These transplant centers may be located within the same OPO service area. These transplant centers may be located within different OPO service areas.").

26. Id.

27. John A. Sten, Comment, Rethinking the National Organ Transplant Program: When Push Comes to Shove, 11 J. ConTEMP. HeAlTH L. \& PoL'y 197, 200 (1994) (noting patients who cannot pay for surgery are not listed).

28. Hainer, supra note 1 .

29. Id.

30. Id.

31. Id.

32. Id.

33. Id.

34. Elkind, supra note 2.

35. UNOS 3.2, supra note 25 . 
Steve Jobs received a liver transplant in a very short amount of time at a transplant center halfway across the country from his home. While the initial, instinctive reaction is to condemn Jobs as unfairly "pushing" his way to the front of the line, the fact of the matter is that he simply followed the express conditions and guidelines of the UNOS policy that allow transplant patients to list themselves at multiple transplant centers. ${ }^{36}$ Presumably, Jobs did what any other person with sufficient financial and physical means would have done. Nonetheless, the heart of the issue centers on the question of whether this "multiple lists" policy allows the wealthy a better, yet unfair, opportunity to receive an organ transplant. Further, even if the current system does allow an advantage to the wealthy, are there sufficient reasons to maintain the status quo?

\section{B. Roadmap}

This Note discusses the practice of patients in need of organ transplants placing themselves on waitlists at multiple transplant centers located around the country. To facilitate understanding of this practice, Section II describes the history of the organ transplant system in the United States, including a discussion of the reasons for implementation of current laws. Section II also includes a description of the current structure and functioning of the organ transplantation process by discussing the relationship between organ transplant centers and organ procurement organizations, and by giving a detailed explanation of UNOS policies that regulate organ allocation. Finally, this section highlights differences in the way that various organ procurement organizations function in distinct areas of the United States. Section III analyzes arguments for maintaining the status quo and for disallowing multiple wait listing. Finally, the Note concludes that current UNOS policies allowing patients to list themselves at multiple transplant centers is the best option.

\section{THE HISTORY AND FUNCTIONING OF THE ORGAN TRANSPLANT SYSTEM IN THE UNITED STATES}

In order to determine whether listings at multiple centers should be allowed by transplant seeking patients, a full understanding of the history and functioning of the Organ Transplant System in the United States is necessary. This section explains the general history of the transplant system and describes legislation regarding the current functioning of the organ transplant process, including a discussion of the differences that occur in various geographical locations across the country. 


\section{A. History}

Researchers began experimenting with the science of organ transplantation in animals and humans in the eighteenth century. ${ }^{37}$ The first successful human kidney transplant was performed in 1954 and the first successful human liver transplant followed in $1967 .^{38}$ Nowadays, transplantation of kidneys, hearts, livers, lungs, pancreases, intestines, and other organs has become routine medical procedure. ${ }^{39}$ During the initial development years of human organ transplant science in the 1950's and 1960's, the decisions, procedures, and policies concerning procurement and allocation of human organs were controlled and made by the medical community ${ }^{40}$ because there were no transplant-specific state or federal laws that governed the process. ${ }^{41}$

As the science of transplantation progressed, ${ }^{42}$ transplant departments at hospitals formed organizations to collect organs from donors. ${ }^{43}$ These Organ Procurement Organizations ("OPOs") were also responsible for distributing donated organs to patients in need. ${ }^{44}$ Without centralized regulation, OPOs developed in different ways with significant variation among the different organizations. ${ }^{45}$ These variations include differences in the number of organs procured, the number of transplants performed at the transplant hospital where the organs are allocated, and the average and median time patients spend on the waitlist until a transplantable organ is found. ${ }^{46}$ Further, there were many private transplantation networks serving specific self-determined regions that all functioned independently of one another. ${ }^{47}$ As a result, there were numerous geographical gaps and overlaps in the organ transplant system. ${ }^{48}$ In fact, transplant hospitals in some areas of the United States would actually compete with other hospitals to get donor organs for transplant, while in other regions there were no transplant

37. Organ Procurement and Transplantation Network, History, HEALTh RES. \& SERV. ADMIN., http://optn.transplant.hrsa.gov/about/transplantation/history.asp (last visited Sep. 15, 2010).

38. Id.

39. Id.

40. Eric F. Galen, Note, Organ Transplantation at the Millennium: Regulatory Framework, Allocation Prerogatives, and Political Interests, 9 S. CAL. INTERDISC. L. J. 335, 336-37 (1999).

41. Id. at 337.

42. S. REP. No. 98-382, at 2 (1984), reprinted in 1984 U.S.C.C.A.N. 3,975, 3976 (providing background and need for legislation based on advances in the science of human organ transplantation).

43. Id at $2-4$ (discussing the number of OPOs in existence at the time); see 42 U.S.C.A. § 273 (West 2003) (providing legal requirements for an organ procurement organization).

44. See 42 U.S.C.A. $\S 273$ (b)(3) (West 2003).

45. Galen, supra note 40 , at 337.

46. Id.

47. S. REP. No. 98-382, at 2-4 (1984), reprinted in 1984 U.S.C.C.A.N. 3,975, 3978.

48. Daubert, supra note 11, at 462 . 
centers at all. ${ }^{49}$

Because of the difficulties presented by the lack of regulation, legislators began enacting state laws addressing organ donation in the $1960 \mathrm{~s}^{50}$ Federal legislation followed, enacted in the $1980 \mathrm{~s}^{51}$ The main purpose of the federal legislation was to intervene in the organ allocation process. ${ }^{52} \mathrm{At}$ this time the federal government acknowledged the progress in the science of human organ transplantation and changed the characterization of heart and liver transplants from "experimental" to "medically appropriate.",53 Because of this change transplant procedures were eligible for coverage under Medicare, Medicaid, and private third-party insurance, making the procedures accessible to more Americans in need. ${ }^{54}$

Prompted by the public's concern about the difficulties of obtaining an organ for transplant, ${ }^{55}$ as well as medico-ethical issues arising in organ transplantation, Congress enacted the National Organ Transplantation Act of 1984 ("NOTA"). ${ }^{56}$ As transplantation became increasingly common, the practice of buying and selling organs through organ brokers became more popular. ${ }^{57}$ Congress felt that the buying and selling of human organs for transplant was against society's ethical and moral values and called the process "supply-side cannibalism." 58 Congress was also fearful that allowing such a system would make the "poor a source of spare parts for the rich.",59 As a result, this federal statute expressly prohibited the commodification of human organs for transplantation. ${ }^{60}$ The statute makes it "unlawful for any person to knowingly acquire, receive, or otherwise transfer any human organ for valuable consideration." ${ }^{, 61}$ Violation of this statute may lead to either imprisonment not greater than five years or fines no greater than $\$ 50,000$, or both. ${ }^{62}$

The term "valuable consideration" does not include

49. Id.

50. Galen, supra note 40 , at 337.

51. National Organ Transplant Act, Pub. L. No. 98-507, 98 Stat. 2339 (1984) (codified as amended at 42 U.S.C. $\S 273-74(2006)$ ).

52. S. REP. No. 98-382, at 1-4 (1984), reprinted in 1984 U.S.C.C.A.N. 3,975-78.

53. Id. at 2-3; see also Galen, supra note 40 , at 337.

54. Galen, supra note 40 , at 338 .

55. S. REP. No. 98-382, at 3 (1984), reprinted in 1984 U.S.C.C.A.N. 3,977.

56. 98 Stat. 2339. See generally 42 U.S.C.A. § 273-4 (West 2003).

57. S. REP. No. 98-382, at 2-4, 16-17 (1984), reprinted in 1984 U.S.C.C.A.N. 3,975, $3978,3,982,39,83$ (showing concern for prohibiting the buying and selling of human organs).

58. Procurement \& Allocation of Human Organs for Transplantation, 1983: Before the Subcomm. on Investigation \& Oversight of the House Comm. on Science \& Tech, 98th Cong. 248 (1983) [hereinafter Hearings]; see also Daubert, supra note 11, at 466.

59. Hearings, supra note 58, at 218; see also Daubert, supra note 11, at 466.

60. 42 U.S.C. $\S 274 \mathrm{e}(2006)$.

61. Id.

62. Id. 
the reasonable payments associated with the removal, transportation, implantation, processing, preservation, quality control, and storage of a human organ or the expenses of travel, housing, and lost wages incurred by the donor of a human organ in connection with the donation of the organ. ${ }^{63}$

Congress had three major goals in passing NOTA. It aimed to articulate a national health policy for organ transplantation, to ensure equitable allocation of donor organs, and to increase the number of organs available for transplantation. ${ }^{64}$ In order to help achieve these goals, Congress created the Task Force on Organ Transplantation, which recommended a system for equitable organ allocation. ${ }^{65}$ The most significant aspect of this system was the establishment of the Organ Procurement and Transplantation Network ("OPTN"). ${ }^{66}$ Medical professionals of the transplant community operate the OPTN. Such operation allows medical judgment to remain paramount while assisting OPOs to ensure equitable allocation of organs on a nationwide basis. ${ }^{67}$ Under NOTA, the OPTN is required to:

1) Maintain a national organ waiting list of organ transplant candidates;

2) Match cadaveric organs with the patients on the waiting list;

3) Establish policies concerning organ allocation;

4) Set quality standards for acquisition and transplantation of organs;

5) Coordinate transportation of organs from OPOs to transplant hospitals;

6) Analyze and publish data concerning transplantation; and

7) Report comparative costs and outcomes concern-

63. 42 U.S.C. $\S 274 \mathrm{e}(\mathrm{c})(2)(2006)$.

64. S. REP. No. 98-382, at 1-4 (1984), reprinted in 1984 U.S.C.C.A.N. 3,975-78; see also Organ Procurement and Transplantation Network, 63 Fed. Reg. 16,296, 16,297 (Apr. 2, 1998) (to be codified at 42 C.F.R. Part 121). See generally 42 U.S.C.A. $\$ 274$ (West 2003).

65. S. REP. NO. 98-382, at 1-2 (1984), reprinted in 1984 U.S.C.C.A.N. 3,975-76; see also Daubert, supra note 11, at 464.

66. 42 U.S.C. $\$ 274(2006)$.

67. 42 U.S.C.A. $\S 274(\mathrm{~b})(2)$ (West 2003); see also Organ Procurement and Transplantation Network, 63 Fed. Reg. 16,296, 16,300 (Apr. 2, 1998) (The U.S. Department of Health and Human Services "believes that the transplantation network must be operated by professionals in the transplant community, and that both allocation and other policies of the OPTN should be developed by transplant professionals. ... It is not the desire or intention of the Department to interfere in the practice of medicine."). 
ing the nation's transplant centers. ${ }^{68}$

NOTA requires the OPTN to be operated by a private, nonprofit corporation. $^{69}$ The United Network for Organ Sharing (UNOS) has performed this job since 1986, and UNOS is the first and only corporation to operate the OPTN. $^{70}$ Keeping with the goal of allowing medical judgment to remain paramount, while assisting OPOs in ensuring equitable allocation of organs on a nationwide basis, the majority of UNOS Board members are doctors and transplant surgeons working at transplant centers. ${ }^{71}$ UNOS actually established the first computerized database used to match donor organs with transplant candidates before NOTA was enacted. ${ }^{72}$

In 1986, federal law made membership with the OPTN and compliance with its policies a prerequisite for payment from Medicare for all hospitals and OPOs. ${ }^{73}$ This was the first time a national entity - UNOS, operating under the United States Department of Health and Human Services' ("HHS") oversight - was charged with developing legally enforceable allocation policies for all hospitals and transplant hospitals across the United States. $^{74}$ Congress believed that funding a national transplant network could resolve many of the inequities that existed in the organ transplant system. ${ }^{75}$ Congress also believed that a centralized computer network would do a better job of matching donors and recipients and that this better matching system would also lead to less donor organs waste. ${ }^{76}$

Although Congress had good intentions in creating the centralized list and matching system, data collected over the first few years of use showed that some patients were receiving organs sooner than others. ${ }^{77}$ Correlations were found between differences in waiting period and geographic location, blood type, ethnicity, and recipient age. ${ }^{78}$ Even worse, data showed that organs were not being consistently given to the patients that were the sick-

68. 42 U.S.C $\$ 274$ (b) (2006).

69. 42 U.S.C. $\$ 274(\mathrm{~b})(1)(\mathrm{A})(2006)$.

70. OPTN, UNITED NETWORK FOR ORGAN SHARING, http://www.unos.org/donation/ index.php?topic=optn (last visited Sep. 15, 2010); see also Galen, supra note 40, at 339.

71. 42 U.S.C. § 274(b)(1)(B) (2006). See generally OPTN, OPTN/UNOS Board of Directors, HEALTH RES. \& SERV. ADMIN., http://optn.transplant.hrsa.gov/members/boardOf Directors.asp (last visited Sep. 15, 2010) (listing current board members).

72. Galen, supra note 40 , at 339 .

73. 42 U.S.C.A $§ 1320(b)(8)$ (West 2006). See generally Organ Procurement and Transplantation Network, 63 Fed. Reg. 16,296, 16,297 (Apr. 2, 1998) (to be codified at 42 C.F.R. Part 121) (giving background information about legislation preceding the 1998 HHS Final Rule). See also Galen, supra note 40, at 339.

74. Galen, supra note 40 , at $339-40$.

75. S. REP. No. 98-382, at 13-44 (1984), reprinted in 1984 U.S.C.C.A.N. 3,979-80; see also Daubert, supra note 11, at 464.

76. S. REP. No. 98-382, at 18 (1984), reprinted in 1984 U.S.C.C.A.N. 3,984 (noting increased transplants would occur due to improved ability to match donors with recipients).

77. Galen, supra note 40 , at 340 .

78. Id. 
est or nearest to death. ${ }^{79}$ In 1998, HHS released a Final Rule concerning these differences. ${ }^{80}$ While this rule did not establish a specific organ allocation system or express rules, ${ }^{81}$ it did direct the OPTN to develop goals for standardized listing criteria to ensure that candidates would be grouped by medical urgency and that organs would be allocated to the sickest patients. ${ }^{82}$

\section{B. Current Structure and Functioning of the Organ Transplantation Process}

In 1999, UNOS developed UNet, the first secure Internet organ transplant database. ${ }^{83}$ It is used to match organ donors and recipients and to manage transplant data ${ }^{84}$ After procuring an organ from a donor, the OPO will enter it into the UNet database and UNOS determines to which patient the organ will be offered first. ${ }^{85}$

\section{The Relationship Between Transplant Centers and Organ Procurement Organizations}

A transplant center is simply a medical facility that performs organ transplantation. ${ }^{86}$ As of March 6, 2010, there were 249 transplant centers in the United States maintaining one or more transplant programs. ${ }^{87}$ Many of these centers offer multiple transplant programs. As of that date, there were 1,135 different transplant programs operating at these 249 centers across the country. ${ }^{88}$ The transplant programs receive their organs for transplant from OPOs. OPOs are non-profit organizations that are responsible for approaching family members of deceased persons to discuss the option of organ donation, evaluating medical suitability of possible organ donors, coordinating recovery, preservation, and transportation of organs to be used for transplantation, and educating the public about the need for organ donation. ${ }^{89}$ Each OPO operates in an established service area, which may cover

79. Id.

80. Organ Procurement and Transplantation Network, 63 Fed. Reg. 16,296 (Apr. 2, 1998) (to be codified at 42 C.F.R. Part 121).

81. Id.

82. Id.

83. UNet Goes Live: Internet-Based Technology Used in Transplant System, UNOS (Oct. 22,1999), http://www.unos.org/about/index.php?topic=newsroom\&article_ id=1548 :9efa7e0fcd11169a248b97671f9cb36b.

84. Id.; see also OPTN, supra note 70.

85. UNet Goes Live, supra note 83.

86. OPTN, Glossary, HEALTH RES. \& SERV. ADMIN., http://optn.transplant.hrsa.gov/ resources/glossary.asp\#T (last visited Sep. 15, 2010).

87. OPTN, Members, HEALTH RES. \& SERV. ADMIN., http://optn.transplant.hrsa.gov/ members/ (last visited Dec. 7, 2010).

88. Id.

89. OPTN, supra note 86 . 
an entire state or only part of a state. ${ }^{90}$ Currently there are fifty-eight OPOs operating across the United States. ${ }^{91}$ Transplant hospitals and OPOs must be members of UNOS in order to receive reimbursement from Medicare. ${ }^{92}$ UNOS has divided the United States into eleven different regions. ${ }^{93}$ This division allows its members to facilitate organ allocation and to provide individuals with the opportunity to identify concerns regarding organ procurement, allocation, and transplantation that are unique to their particular geographic area. ${ }^{94}$ With the exception of perfectly matched donor kidneys, donated organs are offered to recipients in the area from which the organ was procured (where the donation was made) before they are offered to other parts of the country. ${ }^{95}$ UNOS follows this system in order to reduce the time that an organ must be preserved after donation, improve organ quality and survival outcome, reduce the costs associated with transplantation, and increase access to transplantation. ${ }^{96}$

\section{UNOS Policy for Organ Allocation}

UNOS policies prescribe the method in which different organs are to be allocated. ${ }^{97}$ Although UNOS allows patients to list themselves on waiting lists at multiple transplant centers for any organ transplant needed, ${ }^{98}$ this discussion will include only the policies specific to liver allocation for the purposes of simplicity and consistency. ${ }^{99}$ Furthermore, while UNOS policies for liver allocation and transplantation have specific criteria for pediat-

90. OPTN , Regions, HEALTH RES. \& SERV. ADMIN., http://optn.transplant.hrsa.gov/ members/regions.asp (last visited Oct. 16, 2010).

91. OPTN, Member Directory, HEALTH RES. \& SERV. ADMIN., http://optn.transplant. hrsa.gov/members/search.asp (last visited Oct. 16, 2010).

92. 42 U.S.C. $\S 1320(b)(8)(2006)$.

93. OPTN, supra note 90.

94. Id.

95. Id.

96. Id.

97. ORENTLICHER ET AL., supra note 16, at 405.

98. UNOS 3.2, supra note 25.

99. While allocation of each donor organ requires matching to recipients based on organ specific metrics, the allocation algorithm for each organ is similar to that of the liver policies. See generally UNOS, 3.5: Organ Distribution, Allocation of Deceased Kidneys, HEALTH RES. \& SERV. ADMIN., http://optn.transplant.hrsa.gov/PoliciesandBylaws2/ policies/pdfs/policy_7.pdf (last updated Nov. 9, 2010); UNOS, 3.7: Organ Distribution, Allocation of Thoracic Organs, HEALTH RES. \& SERV. ADMIN., http://optn.transplant.hrsa.gov/ PoliciesandBylaws2/policies/pdfs/policy_9.pdf (last updated Nov. 9, 2010); UNOS, 3.8: Organ Distribution, Pancreas Allocation, HEALTH RES. \& SERV. ADMIN., http://optn.transplant.hrsa.gov/PoliciesandBylaws2/policies/pdfs/policy_10.pdf (last updated Nov. 9, 2010); UNOS, 3.11: Organ Distribution, Intestinal Organ Allocation, HEALTH RES. \& SERV.

ADMIN., http://optn.transplant.hrsa.gov/PoliciesandBylaws2/policies/pdfs/policy_13.pdf (last updated June 6, 2008). 
ric patients, ${ }^{100}$ the discussion below examines only the policies as they relate to adult patients. However, all portions of UNOS policy pertinent to this discussion are included below.

UNOS Policy 3.6 governs the process of allocating donor livers to patients on the waiting list. ${ }^{101}$ Compliance with these policies is mandatory, ${ }^{102}$ and UNOS conducts audits when appropriate. ${ }^{103}$ After being placed on a transplant hospital's waiting list, candidates are categorized (and eventually chosen to receive the donor organ) using two methods: status code or probability of candidate death. ${ }^{104}$ Physicians at the transplant center perform patient classification and scoring. ${ }^{105}$

If an adult patient is given a status code, he or she will be given a code of $1 \mathrm{~A}$ or $7 .^{106} \mathrm{~A}$ patient is assigned a status code of 7 when he or she is determined to be temporarily unsuitable for a transplant and is not considered for organ allocation. ${ }^{107}$ A patient is classified as $1 \mathrm{~A}$ when he or she is determined to have "fulminant liver failure with a life expectancy without a liver transplant of less than 7 days." 108 Once given a 1A status code, patients are assigned points under many different categories. These categories include blood type, ${ }^{109}$ time spent waiting on the list, ${ }^{110}$ and degree of medi-

100. See generally UNOS, 3.6: Organ Distribution, Allocation of Livers, HEALTH RES.

SERV. $\quad$ ADMIN., Nov. 9, 2010) [hereinafter UNOS 3.6].

101. Id.

102. Id.

103. UNOS, 3.6.9.2: Organ Distribution, Allocation of Livers, Listing Accuracy and Appropriateness, HEALTH RES. \& SERV. ADMIN., http://optn.transplant.hrsa.gov/ PoliciesandBylaws2/policies/pdfs/policy_8.pdf (last updated Nov. 9, 2010) ("Any instance in which an organ is allocated to a recipient center for a transplant candidate and the Host OPO or any Member questions the accuracy or appropriateness of the candidate's status may be reported retrospectively to the Host OPO's Regional Review Board with reasons for the concern. Upon receipt of two such reports regarding cases from the same institution within a one-year period, the Review Board shall refer the matter to the Membership and Professional Standards Committee with a request for an on-site audit of the institution. ").

104. UNOS, 3.6.4.1: Organ Distribution, Allocation of Livers, Adult Candidate Status, HEALTH RES. \& SERV. ADMIN., http://optn.transplant.hrsa.gov/PoliciesandBylaws2/ policies/pdfs/policy_8.pdf (last updated Nov. 9, 2010) [hereinafter UNOS 3.6.4.1].

105. UNOS 3.6, supra note 100.

106. Id.

107. UNOS 3.6.4.1, supra note 104.

108. Id. (UNOS Policy 3.6.4.1 defines "fulminant" in detail, but for the purpose of this note it is sufficient (and most important) to understand that patients placed in the 1A category have liver failure and have a life expectancy of less than 7 days.).

109. UNOS, 3.6.2: Organ Distribution, Allocation of Livers, Blood Type Similarity Stratification/Points, HEALTH RES. \& SERV. ADMIN., http://optn.transplant.hrsa.gov/ PoliciesandBylaws2/policies/pdfs/policy_8.pdf (last updated Nov. 9, 2010) [hereinafter UNOS 3.6.2] (Patients with the same blood type as the donor receive ten points. Patients with compatible, but not identical blood types receive five points. Patients with a blood type that is incompatible with the donor receive zero points.).

110. UNOS, 3.6.3: Organ Distribution, Allocation of Livers, Time Waiting, HEALTH RES. \& SERV. ADMIN., http://optn.transplant.hrsa.gov/PoliciesandBylaws2/policies/ 
cal urgency. ${ }^{111}$

When a patient does not fit the criteria to be placed in a given status code, he or she may still receive an organ based on probability of death. ${ }^{112}$ A mortality risk score is determined by the physician using different medical prognostic factors ${ }^{113}$ as provided by the Model for End-Stage Liver Disease (MELD) Scoring System. ${ }^{114}$ Once given a MELD score, patients are then grouped by blood type. ${ }^{115}$ Within each MELD score, donor livers are offered to patients who have an identical blood type match first, followed by those patients who are blood-type compatible, followed by patients who are blood-type incompatible with the donor. ${ }^{116}$

Once a patient is listed and given a status code or MELD score, he or she must wait for a donor organ. ${ }^{117}$ As a patient's health changes, the scores and categorization of the patient will change. ${ }^{118}$ UNOS requires doctors to reassess and recertify patients' status code and probability of death determination at a predetermined frequency depending upon the last score or categorization. ${ }^{119}$ When a liver becomes available, it is offered to patients based on their current status code or MELD score according to the following algorithm. Patients listed at a transplant hospital located in the same geographic region from where the organ was harvested with a status code of $1 \mathrm{~A}$ are considered first by descending point total. ${ }^{120} \mathrm{Next}$, candidates in the same geographic region are considered by descending MELD score. $^{121}$ Finally, if there are no regional patients that are able to take the donor liver, ${ }^{122}$ the liver is offered to patients in the same priority on a national level. ${ }^{123}$

pdfs/policy_8.pdf (last updated Nov. 9, 2010) (Time spent on the waiting list only accrues while the patient is active (suitable for transplant). Ten points are awarded to the patient that has been waiting the longest period and proportionately fewer points are accrued by those patients who have been waiting a shorter period of time.).

111. UNOS, 3.6.4: Organ Distribution, Allocation of Livers, Degree of Medical Urgen$c y$, HeAlTH RES. \& SERV. ADMIN., http://optn.transplant.hrsa.gov/PoliciesandBylaws2/ policies/pdfs/policy_8.pdf (last updated Nov. 9, 2010).

112. UNOS 3.6, supra note 100.

113. As with tests used to determine the patient's status code, the specific medical criterion used in the MELD test is of no importance to this discussion. Knowledge of its use is sufficient.

114. UNOS 3.6, supra note 100; see also UNOS 3.6.4.1, supra note 104.

115. UNOS 3.6, supra note 100 .

116. UNOS 3.6.2, supra note 109.

117. See generally UNOS 3.6, supra note 100.

118. Id.

119. UNOS, 3.6.4.1.1: Organ Distribution, Allocation of Livers, Adult Candidate Reassessment and Recertification, HEALTH RES. \& SERV. ADMIN., http://optn.transplant.hrsa.gov/ PoliciesandBylaws2/policies/pdfs/policy_8.pdf (last updated Nov. 9, 2010).

120. UNOS 3.6, supra note 100.

121. Id.

122. Id. (UNOS leaves the final determination - whether to use the donor organ - with the transplant surgeon. This allows the surgeon to exercise judgment over the suitability of transplantation of the donor organ into the specific patient. If the surgeon decides not to use the liver, it must be returned to UNOS for allocation.).

123. Id. 
As noted above, when determining organ allocation, the criterion given the greatest weight is medical urgency. However, when these factors place potential recipients into the same status, a recipient that is "regional" will receive preference over those patients who are not. Yet, these UNOS guidelines do not govern the transplant process until after the patient is on the waiting list. ${ }^{124}$

While much attention is given to the shortage of donated organs as compared to the number of potential recipients on the waitlist, attention should also be paid to the process of adding one's name to the waitlist. According to Arthur Caplan, Ph.D., the chair of the Department of Medical Ethics at the University of Pennsylvania, "The system works at two levels ... . One, who gets in to a [transplant] center. Two, who gets transplanted off a particular center's list when an organ becomes available. Most of the attention goes to stage two, but the biggest ethical challenges are really at stage one." 125

\section{Not All Organ Procurement Organizations Are Created Equal}

If all transplant centers had similar access to organs, patients needing an organ transplant would gain no advantage by listing themselves on multiple waiting lists. This, however, is not the case.

The problem - or the advantage for some patients - is that not all OPOs are created equal. Some regions contain nearly fifteen times as many people as others, and their waiting list times vary widely. Patients in small OPOs tend to be less sick and experience shorter wait times before getting an organ. ${ }^{126}$

Examining the performance of the fifty-eight OPOs across the United States shows a significant variation among them. For example, the tables below show statistics for 2007 and 2008 for OPOs located in and serving California (where Steve Jobs lives) and Tennessee (where Steve Jobs received his liver transplant). While Tennessee Donor Services serves the less populous state of Tennessee, ${ }^{127}$ in 2007 and 2008 it actually outperformed California's Golden State Donor Services. Tennessee Donor Services procured more organs overall, more organs per donor, more organs

124. ORENTLICHER ET AL., supra note 16, at 409.

125. Hainer, supra note 1.

126. Id.

127. U.S. Census Bureau, Statistical Abstract of the United States: 2008, 17-18 (2008), available at $\mathrm{http}: / /$ www.census.gov/prod/2007pubs/08abstract/pop.pdf (stating that in 2006, California ranked first among states in terms of population with $36,458,000$ residents, while Tennessee ranked seventeenth with $6,039,000$ residents). 
transplanted per donor, and more of that OPO's organs were actually used for transplant (see Tables 1 and 2 below). Further, Golden State Donor Services fell below the United States average for all of these categories while Tennessee Donor Services exceeded the nationwide average in both years (See Tables 1-3 below).

Table 1: California - Golden State Donor Services ${ }^{128}$

\begin{tabular}{lllll}
\hline Year & $\begin{array}{l}\text { Total Organs } \\
\text { Recovered }\end{array}$ & $\begin{array}{l}\text { Organs } \\
\text { Recovered Per } \\
\text { Donor Type }\end{array}$ & $\begin{array}{l}\text { Organ Transplants } \\
\text { Per Donor Type }\end{array}$ & $\begin{array}{l}\text { Transplants Performed } \\
\text { Using Organs Procured } \\
\text { by this Organization }\end{array}$ \\
2007 & 178 & 3.18 & 2.86 & 160 \\
2008 & 184 & 3.17 & 2.91 & 169
\end{tabular}

Table 2: Tennessee - Tennessee Donor Services ${ }^{129}$

\begin{tabular}{lllll}
\hline Year & $\begin{array}{l}\text { Total Organs } \\
\text { Recovered }\end{array}$ & $\begin{array}{l}\text { Organs } \\
\text { Recovered Per } \\
\text { Donor Type }\end{array}$ & $\begin{array}{l}\text { Organ Transplants } \\
\text { Per Donor Type }\end{array}$ & $\begin{array}{l}\text { Transplants Performed } \\
\text { Using Organs Procured } \\
\text { by this Organization }\end{array}$ \\
\hline 2007 & 717 & 3.66 & 3.12 & 612 \\
\hline 2008 & 717 & 3.81 & 3.19 & 599 \\
\hline
\end{tabular}

Table 3: United States Average ${ }^{130}$

\begin{tabular}{lll}
\hline Year & $\begin{array}{l}\text { Organs Recovered Per Donor } \\
\text { Type }\end{array}$ & $\begin{array}{l}\text { Organs Transplants Per } \\
\text { Donor Type }\end{array}$ \\
\hline 2007 & 3.5 & 3.0 \\
\hline 2008 & 3.49 & 3.0 \\
\hline
\end{tabular}

\section{Not All Transplant Centers Are Created Equal}

Even if all OPOs were able to provide donor organs equally to all transplant centers, a difficulty for patients would remain. Not all transplant centers provide the same transplant services. In other words, not all transplant hospitals have programs for transplantation of all organs. In addition, waitlist numbers and procedures performed vary greatly between centers. Further, as shown by Tables 4 and 5, not all centers have the same patient survival rates.

128. SRTR, Golden State Donor Services, SaCramento, CA, CAGSOPiXX, 5 (JULY 2009), available at http://www.ustransplant.org/cst/archives/200906/CAGSOP1XX2 00906.PDF.

129. SRTR, TenNessee Donor Services, NAShVIlle, TN, TNDSOP1XX, 5 (JUly 2009), available at http://www.ustransplant.org/cst/archives/200906/TNDSOP1XX2009 06.PDF.

130. SRTR, supra note 128. 
As shown in Tables 4 and 5, various transplant centers located in different areas of the United States function quite differently. Transplants performed using deceased donors varied widely between centers within the same state as well as those located in different states. The number of patients on each center's waitlist also varied greatly. At first glance, these statistics appear to show the rate at which patients are given transplants. This, however, is not the case. Instead, these numbers show the relative consistency in the number of patients waiting at each transplant center. In addition, it is important to note that the centers differ from one another in the rate of transplants performed, adult graft survival rate, and adult patient survival rate one year after transplant surgery. These differences indicate that, as with any other medical treatment or procedure, organ transplant outcomes vary at different centers across the United States.

\section{Table 4: Sample of Transplant Centers Performing Kidney} Transplants in California - 2008 ${ }^{131}$

\begin{tabular}{|c|c|c|c|c|c|c|}
\hline $\begin{array}{l}\text { Transplant } \\
\text { Center }\end{array}$ & $\begin{array}{l}\text { Deceased } \\
\text { Donor } \\
\text { Trans- } \\
\text { plants } \\
\text { Performed }\end{array}$ & $\begin{array}{l}\text { Patients on } \\
\text { Center's } \\
\text { Waitlist at } \\
\text { Beginning } \\
\text { of } 2008\end{array}$ & $\begin{array}{l}\text { Patients } \\
\text { on } \\
\text { Center's } \\
\text { Waitlist } \\
\text { at End } \\
\text { of } 2008\end{array}$ & $\begin{array}{l}\text { Transplant } \\
\text { Rate Among } \\
\text { Waitlisted } \\
\text { Patients }\end{array}$ & $\begin{array}{l}\text { Adult } \\
\text { Graft } \\
\text { Survival } \\
\text { Rate }\end{array}$ & $\begin{array}{l}\text { Adult } \\
\text { Patient } \\
\text { Survival } \\
\text { Rate } \\
\text { One } \\
\text { Year } \\
\text { After } \\
\text { Surgery } \\
\end{array}$ \\
\hline $\begin{array}{l}\text { Arrowhead } \\
\text { Regional } \\
\text { Medical } \\
\text { Center }\end{array}$ & 4 & 74 & 69 & $\begin{array}{l}\text { "Statistically } \\
\text { lower" than } \\
\text { expected }\end{array}$ & $\begin{array}{l}\text { "Not } \\
\text { statistical- } \\
\text { ly differ- } \\
\text { ent" than } \\
\text { expected }\end{array}$ & $\begin{array}{l}\text { "Not } \\
\text { statisti- } \\
\text { cally } \\
\text { differ- } \\
\text { ent" than } \\
\text { expected }\end{array}$ \\
\hline $\begin{array}{l}\text { Cedars- } \\
\text { Sinai Med- } \\
\text { ical Center }\end{array}$ & 100 & 473 & 258 & $\begin{array}{l}\text { "Statistically } \\
\text { higher" than } \\
\text { expected }\end{array}$ & $\begin{array}{l}\text { "Not } \\
\text { signifi- } \\
\text { cantly } \\
\text { different" } \\
\text { than } \\
\text { expected }\end{array}$ & $\begin{array}{l}\text { "Not } \\
\text { signifi- } \\
\text { cantly } \\
\text { differ- } \\
\text { ent" than } \\
\text { expected }\end{array}$ \\
\hline
\end{tabular}

131. SRTR, Arrowhead Regional Medical Center, Colton, CA, CASBTX1Ki (July 2009), available at http://www.ustransplant.org/csr/archives/200906/CASBTX1KI 200906.PDF; SRTR, Cedars-SinaI Medical Center, Los ANGEles, CA, CACSTX1KI (July 2009), available at http://www.ustransplant.org/csr/archives/200906/CACSTX1KI 200906.PDF. 
Table 5: Sample of Transplant Centers Performing Kidney Transplants in Tennessee $-\mathbf{2 0 0 8}^{132}$

\begin{tabular}{|c|c|c|c|c|c|c|}
\hline $\begin{array}{l}\text { Transplant } \\
\text { Center }\end{array}$ & $\begin{array}{l}\text { Deceased } \\
\text { Donor } \\
\text { Trans- } \\
\text { plants } \\
\text { Performed }\end{array}$ & $\begin{array}{l}\text { Patients on } \\
\text { Center's } \\
\text { Waitlist at } \\
\text { Beginning } \\
\text { of } 2008\end{array}$ & $\begin{array}{l}\text { Patients } \\
\text { on Cen- } \\
\text { ter's } \\
\text { Waitlist } \\
\text { at End } \\
\text { of } 2008\end{array}$ & $\begin{array}{l}\text { Transplant } \\
\text { Rate Among } \\
\text { Waitlisted } \\
\text { Patients }\end{array}$ & $\begin{array}{l}\text { Adult } \\
\text { Graft } \\
\text { Survival } \\
\text { Rate }\end{array}$ & $\begin{array}{l}\text { Adult } \\
\text { Patient } \\
\text { Survival } \\
\text { Rate One } \\
\text { Year } \\
\text { After } \\
\text { Surgery } \\
\end{array}$ \\
\hline $\begin{array}{l}\text { Centennial } \\
\text { Medical } \\
\text { Center }\end{array}$ & 31 & 158 & 159 & $\begin{array}{l}\text { "Statistically } \\
\text { higher" than } \\
\text { expected }\end{array}$ & $\begin{array}{l}\text { "Statisti- } \\
\text { cally } \\
\text { lower" } \\
\text { than } \\
\text { expected }\end{array}$ & $\begin{array}{l}\text { "Not } \\
\text { statistical- } \\
\text { ly differ- } \\
\text { ent" than } \\
\text { expected }\end{array}$ \\
\hline $\begin{array}{l}\text { Nashville } \\
\text { Veterans } \\
\text { Administra- } \\
\text { tion } \\
\text { hospital }\end{array}$ & 15 & 179 & 193 & $\begin{array}{l}\text { "Statistically } \\
\text { lower" than } \\
\text { expected }\end{array}$ & $\begin{array}{l}\text { "Not } \\
\text { signifi- } \\
\text { cantly } \\
\text { differ- } \\
\text { ent" than } \\
\text { expected }\end{array}$ & $\begin{array}{l}\text { "Not } \\
\text { signifi- } \\
\text { cantly } \\
\text { different" } \\
\text { than } \\
\text { expected }\end{array}$ \\
\hline
\end{tabular}

\section{UNOS Allows Multiple Listings}

Current UNOS Policies and Bylaws expressly allow patients in need of an organ transplant to be listed on multiple waiting lists. ${ }^{133}$ In fact, each transplant program must inform all patients of the option to be listed at multiple centers upon accepting that patient onto its waiting list. ${ }^{134}$ In order to avoid inefficiencies, UNOS policies prescribe procedures to remove a patient from all of the lists he or she is on soon after that patient receives a transplant or dies. ${ }^{135}$

132. SRTR, CENTENNIAL MEDICAL CENTER, NASHVILle, TN, TNPVTX1KI (July 2009), available at http://www.ustransplant.org/csr/archives/200906/TNPVTX1KI200906.PDF; SRTR, CENTENNIAL MEDICAL CENTER, NASHVILLE, TN, TNPVTX1KI (July 2009), available at http://www.ustransplant.org/csr/archives/200906/TNPVTX1KI200906.PDF.

133. UNOS 3.2, supra note 25.

134. UNOS, 3.2.3: Organ Distribution, UNOS Patient Waiting List, Waiting Time Transferral and Multiple Listing, HEALTH RES. \& SERV. ADMIN., http://optn.transplant. hrsa.gov/PoliciesandBylaws2/policies/pdfs/policy_4.pdf [hereinafter UNOS 3.2.3] (last updated Nov. 9, 2010).

135. See generally UNOS, 3.2.2: Organ Distribution, UNOS Patient Waiting List, Multiple Listings Permitted, HEALTH RES. \& SERV. ADMIN., http://optn.transplant.hrsa.gov/ PoliciesandBylaws2/policies/pdfs/policy_4.pdf (last updated Nov. 9, 2010); UNOS 3.2.3, supra note 132; UNOS, 3.2.4: Organ Distribution, UNOS Patient Waiting List, Match System Access, HeAlTH RES. \& SERV. ADMIN., http://optn.transplant.hrsa.gov/PoliciesandBylaws2/ policies/pdfs/policy_4.pdf (last updated Nov. 9, 2010). 


\section{PATIENTS IN NEED OF AN ORGAN TRANSPlant SHOULd CONTINUE TO BE AlLOWED to Place THEMSELVES ON THE WAIT LIST AT MULTIPLE TRANSPLANT CENTERS}

One possible way to stop the potential inequities of the current system would be to limit patients to listing themselves at local transplant centers only. If the current system for organ allocation and transplantation should be changed, now might be an opportune time to do so. An overhaul of health care in the United States is currently underway, ${ }^{136}$ and legislators have a prime opportunity to change systems that they find inefficient as the changes called for in the law are being shaped. However, the appropriateness of the timing alone does not mean that the system should be changed. The system should be changed only if the changes would prove to be advantageous to the general transplant patient population overall.

\section{A. Arguments in Favor of Allowing Patients to Place Themselves on Multiple Waitlists}

\section{Patient Autonomy in Treatment Choices}

The marketplace in the United States is generally based on a "freemarket" system. ${ }^{137}$ This system allows consumers to choose the products and services that they wish to purchase. ${ }^{138}$ This freedom of consumer choice may create incentives for companies and individuals who sell goods and services to create the highest quality products at the lowest possible price. $^{139}$ This freedom of choice is also a notable aspect of the United States health care system. Like the free market system in place for consumer goods, this system likely gives doctors and hospitals incentive to provide the highest quality of care. While prices in healthcare are more likely to be determined by, or in the least influenced by, the federal government (by setting payment schedules for Medicare) and private insurance and third party payers, the quality of patient care will still be affected by this freedom of choice. In the end, patient safety and quality outcomes are the most important aspects of health care.

As shown previously in this note, OPOs functioning in different re-

136. See generally Patient Protection and Affordable Care Act, Pub. L. No. 111-148, 124 Stat. 119 (2010) (to be codified as amended at scattered sections of 42 U.S.C.), available at http://www.gpo.gov:80/fdsys/pkg/PLAW-111 publ148/pdf/PLAW-111 publ148.pdf.

137. Frederick C. Thayer, Regulation is Inevitable: Legal Planning or Illegal Collusion?, 32 AM. U. L. REV. 425, 425-26 (1983). See also Josh Clark, Is A FrEE MARKET "FrEE" IF IT'S REGULATED? (Oct. 3, 2008), http://money.howstuffworks.com/free-market-economy .htm (suggesting that the United States marketplace is based on the idea of a free market but is also regulated by the government).

138. See Clark, supra note 137.

139. Id. 
gions provide patients with different opportunities to receive the organ they need. ${ }^{140}$ Tables 1 and 2 showed the different amounts of organs that are recovered throughout the region that each OPO served. Table 3 showed that some OPOs function at levels below the national average and others exceed national figures. Further, Tables 4 and 5 showed that different transplant centers have different outcomes in their transplantation programs. These outcome based differences include the number of transplants performed, the way the actual number of transplants performed compared to the number of expected transplants the hospital, and varying outcomes from the actual transplant surgery, which include graft survival rates and, more importantly, patient survival rate one-year post surgery.

Patients who are on a waitlist for organ transplant are often in a life or death situation. If they do not receive the organ they need, death may be the likely outcome. On the other hand, receiving a necessary organ can be a sort of "stay of execution" in that it places the patient in a situation where a return to healthy living is possible to some extent. In almost any other situation where an adult patient is in need of medical treatment, the patient is granted the right to consent, or deny consent, for that treatment. ${ }^{141}$ If all financial variables are set aside, and the patient consents to treatment, he or she should have the right to choose from which doctor to seek treatment. Undoubtedly, this decision is made by weighing multiple factors including, but not limited to, treatment availability and outcomes, rapport with the doctor and surgeon, the experience or expertise of the doctor and surgeon, and hospital reputation. The current system permitting patients to list themselves at multiple transplant hospitals reserves the patient's decisionmaking autonomy by allowing the patient to determine what doctors and surgeons he or she feels most comfortable with. The current system also allows the patient to seek transplant centers with the best outcomes. Because different OPOs function at different levels, requiring a patient to only be listed at the nearest transplant center may force the patient to be treated at a center that provides a lesser chance of survival. Certainly if a patient is allowed to make the choice of which doctor to go to for a simple yearly physical examination, the same autonomy should be allowed in a decision with the gravity of life and death.

While many patients do have health insurance, it may not cover the entire expense of organ transplantation surgery or aftercare. For example, Medicare pays for the direct cost of transplantation of many different or-

140. See supra notes $128-132$ and accompanying text and tables.

141. See generally In re Conroy, 486 A.2d 1209, 1226 (N.J. 1985) (holding that a competent patient has the right to give and deny consent for treatment absent a third party interest); McFall v. Shimp, 10 Pa. D. \& C.3d 90, 91-92 (Allegheny County 1978) (holding that a patient has the right to refuse unwanted bodily intrusion); ORENTLICHER ET AL., supra note 16 , at $355-56$. 
gans, but it does not cover all the costs associated with the transplant. ${ }^{142}$ Private insurance, similar to Medicare, often offers incomplete coverage of transplant costs. ${ }^{143}$ This incomplete coverage may preclude patients, under private insurance or Medicare, from receiving a transplant at a hospital out of their financial reach. The current system would allow a patient to place him or herself on waitlists at transplant centers that are most affordable in his or her financial situation. A system that would require patients to go to their local center might price patients out of the ability to have their surgery.

As previously mentioned, many transplant hospitals do not perform transplants of every organ. Further, the type of available organs varies widely between different geographic areas of the United States. ${ }^{144} \mathrm{~A}$ regulation limiting patients to listing themselves with local centers may bar some patients from the surgery they would need to live based solely on availability. Clearly, a regulation having this effect would require an exception for a patient in such a situation.

The criteria used to decide whether or not to place a patient on a wait list vary between physicians and transplant centers. ${ }^{145}$ In addition, because UNOS does not have regulations that mandate how transplant centers operate, there can be a large variation in transplant center practices. ${ }^{146}$ The current system allows patients to find a surgeon and transplant center that have criteria the patient satisfies so he or she can be placed on the wait list. Also, the system allows patients to list themselves at transplant centers where they feel most confident in the transplant process. A system allowing only local wait listing might both keep patients in need from getting on a wait list (if they were not able to satisfy the requirements for entrance onto the local list) and force patients to list themselves at a facility where they are not confident in the possible outcome.

To alleviate the problems that would arise in limiting patients to only list themselves at the local transplant center, UNOS could limit each patient to one entry on a waiting list without geographic limitation. However, in this situation the argument for inequality would still exist, because patients with modest financial means would be unable to travel to a transplant center located far from their home, while a wealthy patient could travel to different centers and decide which gave him or her the best opportunity for a suc-

142. ORENTLICHER ET AL., supra note 16, at 404.

143. Id.

144. UNOS Rationale for Objectives of Equitable Organ Allocation, UNOS (Jan. 15, 1996), http://www.unos.org/about/index.php?topic=newsroom\&article__ id=1503: 85b3dc451eb0ded52b3121dc59c438dc.

145. See generally ORENTLICHER ET AL., supra note 16, at 403-4 (suggesting that different transplant centers give different weight to factors including, but not limited to, the likelihood of successful surgery, ability to pay, benefit the particular patient will gain from the transplant, organ rejection, quality of life, cause of organ failure (such as alcoholism in liver failure), concomitant illness, age, drug abuse, and mental status).

146. UNOS Rationale for Objectives of Equitable Organ Allocation, supra note 144. 
cessful outcome. Thus, limiting a patient to only one listing based on geography does not alleviate the possibility of inequality between the rich and the poor. While the current system can be criticized for potential inequality due to financial means, it appears to be better than these other two options. The first alternative infringes upon patient autonomy in treatment and potentially decreases successful outcomes by forcing patients to wait at a particular center irrespective of organ availability in that region, center procedure, and outcome statistics. The second alternative does not alleviate the latent inequality that may exist within the present system.

\section{Multiple Wait Listing May Potentially Help Patients Who Are Only on a Single List}

One might argue that the current system creates an inequality that favors the wealthy; however, this system has the potential to help those listed only on a single local list as well. A wealthy patient who gets a necessary organ transplant at a center outside of his or her locality will then be removed from (or not even placed on) the local list. ${ }^{147}$

For example, consider Patient $\mathrm{X}$ and Patient $\mathrm{Y}$ who have the same blood type, need the same organ, and are given the same MELD score. Patient $\mathrm{X}$ and Patient $\mathrm{Y}$ are both listed at Transplant Hospital 1, but Patient $\mathrm{X}$ was placed onto the wait list one day before Patient $Y$. The median wait time at Transplant Hospital 1 is much higher than the national average. If Patient $\mathrm{X}$ has the financial and physical means to travel around the United States and to be listed at Transplant Hospitals 2, 3, 4, and 5, his chances of getting the needed organ before death significantly increase. Patient $Y$ does not have the financial and physical means to be listed at all of these centers. However, Patient Y may still benefit from the current system. If Patient X receives an organ transplant from any of Transplant Hospitals 2-5, he will immediately be removed from the waitlist at Transplant Hospital 1. Thus, an organ that would have gone to Patient $X$ will go to Patient $Y$ instead. If Patient $\mathrm{X}$ had been required to list himself only at a single local center, $\mathrm{Pa}$ tient $\mathrm{Y}$ would not receive this benefit. ${ }^{148}$

147. UNOS, 3.2.2.3: Organ Distribution, UNOS Patient Waiting List, UNET Notification Of Transplantation Or Death Of Multiple Listed Candidates, HEALTH RES. \& SERV. ADMIN., http://optn.transplant.hrsa.gov/PoliciesandBylaws2/policies/pdfs/policy_4.pdf (last updated Nov. 9, 2010) ("Transplant centers will be notified through the UNet system when a multiple listed candidate has been transplanted or reported as deceased by another center so that all other centers involved can investigate and request removal of the candidate from the center's Waiting List.").

148. The counter to this argument is that Patient $\mathrm{X}$ took an organ from a third patient listed at Transplant Hospital 2-5 who only had the financial means to list himself at one of these transplant hospitals. See discussion infra at Part III.B.2. 


\section{Economic Argument}

Allowing those with the financial and physical means to place themselves on multiple waitlists can benefit society. Steve Jobs' case is a good example of this. Apple is a company that has benefitted greatly from its CEO's actions. ${ }^{149}$ Jobs was one of the founding fathers of the company and under his leadership Apple's worth has grown from $\$ 5$ billion in 2000 to $\$ 170$ billion in $2009 .{ }^{150}$ If Jobs was limited to a single wait list, he likely would have undergone his transplant later or died. Under either of these scenarios, Apple would have suffered with the loss or prolonged illness of its CEO. ${ }^{151}$ Allowing someone with the financial means to decrease the time spent waiting for a transplant improved the lives of those who benefit from Apple products.

The current system also has a financial impact on the public. If Jobs was not able to return to his company as quickly as he did (or if he died as a result of not receiving a transplant), Apple's stock prices might have decreased further, and those with money in the market would have suffered if they had invested in Apple. More directly, Apple is a large corporation that

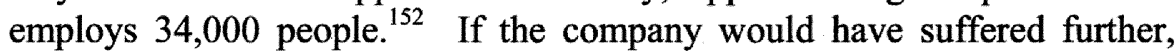
many of its employees could have lost their jobs. Further, someone left unemployed may also be left without health insurance, and if she also needed a transplant, she may be left with no ability to pay for the procedure. As previously discussed, inability to pay may preclude a patient from even being entered onto a wait list, ${ }^{153}$ and death may occur as a result. Obviously, not every organ recipient has as direct an impact on the economy as Steve Jobs does. However, a recipient who has the financial means to place him or herself on multiple waitlists likely does effect the economy in a similar manner, only on a smaller scale. Further, in the case that another prominent figure in the business world is in need of an organ transplant, allowing him or her to be placed on multiple waitlists will allow the same positive economic benefit.

149. Adam Lashinsky, The Decade of Steve: How Apple's Imperious, Brilliant CEO Transformed American Business, CNN MONEY (Nov. 5, 2009), http://money.cnn.com/ 2009/11/04/technology/steve_jobs_ceo_decade.fortune/index.htm.

150. Id.

151. Steve Jobs Takes Medical Leave, Apple Stocks Plunge, LIVEMINT \& THE WALL STREET JouRNAL (Jan. 15, 2009), http://www.livemint.com/2009/01/15092803/Steve-Jobstakes-medical-leave.html (explaining that the price of Apple's stock dropped $7.07 \%$ in the hours following Jobs' announcement that he would be taking a leave of absence related to his medical issues).

152. Lashinsky, supra note 149.

153. ORENTLICHER ET AL., supra note 16, at 404; see also Hainer, supra note 1. 
4. Enforcing Wait Time Equity Frustrates the Two Goals of HHS in Relation to Organ Transplantation

\section{a. Minimal waste of organs}

The time interval between procurement of an organ from the donor and surgical transplant into the patient is referred to as "cold ischemia time." "154 As cold ischemia time increases, the likelihood of successful organ transplantation decreases. ${ }^{155}$ Therefore, one important factor in minimizing waste of organs is to ensure that they are transplanted as quickly as possible in order to keep cold ischemia time to a minimum.

As described above, ${ }^{156}$ UNOS policies for organ allocation offer an organ to the patient with a status code of $1 \mathrm{~A}$ and the highest point total who is at a hospital located in the same vicinity where the organ is procured. ${ }^{157}$ If the transplant surgeon decides that the organ received is not suitable for transplant in a particular patient, the organ is allocated to the next best candidate. $^{158}$ Often, this candidate may be at a different transplant center. When this occurs, the donor organ must be transported to the center. After being offered locally, the organ is then offered on a nationwide basis. ${ }^{159}$ Obviously, as the distance between the donation site and the transplant center that accepts the organ increases, the time taken to transport the organ increases. While this process occurs, the time that the donor organ goes without perfusion of blood (the cold ischemia time) increases and the likelihood of successful transplantation decreases. Because the transplant surgeon ultimately decides whether an organ is appropriate for transplantation into a patient based on his or her medical judgment, and because the amount of cold ischemia time is one predictor of successful transplantation, it is highly likely that a surgeon will decline an organ that has a high cold ischemia time. After an organ is declined for transplant into the first potential recipient, it becomes increasingly likely that the organ may not be used due to cold ischemia time. What was initially a valuable organ can become unusable and therefore wasted.

Allowing multiple listing can help decrease the chance of wasted or-

154. Glossary of Relevant and Related Terms: Cold Ischemia Time (CIT), SRTR, http://www.ustransplant.org/glossary.aspx?term $=$ Cold\%20Ischemia\%20Time\%20(CIT) (last visited Oct. 16, 2010)

155. James E. Stahl et al., Consequences of Cold-Ischemia Time on Primary Nonfunction and Patient and Graft Survival in Liver Transplantation: A Meta-Analysis, PLos ONE, 67 (June 6, 2008) http://www.plosone.org/article/info:doi\%2F10.1371\%2Fjournal.pone. 0002468 .

156. See discussion of UNOS liver allocation policies, supra notes 99-125 and accompanying text.

157. UNOS 3.6, supra note 100.

158. $I d$.

159. Id. 
gans due to increased cold ischemia time by placing a patient who may be the best fit for a transplant in multiple localities. The same financial resources that allowed the patient to list him or herself at transplant centers across the country will also usually allow him or her to travel quickly to the area where the donor organ is procured. In other words, if a perfectly matched organ is procured at a distance from the patient's home, he or she can travel quickly to the center during the procurement process to the local hospital in that area to decrease cold ischemia time. When this occurs, the organ will be offered to a patient who is a perfect fit rather than the next patient down the list who may not have been as good a fit. The chance of the transplant surgeon declining the organ will decrease, thus decreasing the possibility of organ wasting. In the case of Steve Jobs, it was determined that he would be the best match for an organ procured in Tennessee. His financial means allowed him to travel from California to Tennessee quickly enough to keep the cold ischemia time of the donor liver to a minimum, allowing for a successful transplantation. Further, by placing himself on multiple lists, Jobs was able to minimize the problem of a high cold ischemia and increase the likelihood that an organ matching his specific needs would be found. When an organ matches well with the recipient, the chances of a surgeon declining it are usually minimal and the organ will not go to waste.

\section{b. Maximum survival rates}

(I) Better matching between donor organ and recipient.

In order for survival rates to remain high, organs must be matched well to recipients. ${ }^{160}$ When an organ becomes available, it is first offered to a patient with a 1A status code and the highest point score in the same locality from which the donor organ was procured. ${ }^{161}$ As discussed above, ${ }^{162}$ when a patient appears on multiple lists, the chance that an organ will go to a well matched recipient increases because he or she is considered based on medical criteria rather than geographic location. Thus, the organ is more likely to be matched with a recipient patient needing an organ of that size, blood type, and other pertinent criteria.

(II) Transplant tourism.

In 2007, the United Nations expressed concerns about a rising number of "transplant tourism" cases - where people in countries including Paki-

160. This is evidenced by the allocation policies that give priority scoring to patients with the same or similar medical characteristics such as blood type. See UNOS 3.6, supra note 100 .

161. Id.

162. There is an increased likelihood of a good match between first potential recipient and the offered donor organ; therefore, there is a decreased chance that a surgeon would decline the organ for that particular patient. See supra note 122. 
stan, Egypt, and the Philippines were selling their body parts to people from other countries. ${ }^{163}$ Because of advancements in transplantation surgery, more patients seek, and are eligible for, organ transplantation. ${ }^{164}$ However, waiting lists have remained long and some wealthy patients have turned to purchasing organs and tissues that are not essential for survival from the less fortunate in other countries. ${ }^{165}$ Farhat Moazam of the Sindh Institute of Urology and Transplantation notes the increased number of people traveling to Pakistan to buy kidneys, saying, "There are villages that are in the poorer parts of Pakistan where as many as 40 to 50 percent of the population of the village we know only has one kidney." This is a prime example of the fear that Congress had of making the "poor a source of spare parts for the rich" when it enacted NOTA. ${ }^{166}$

While the practice of transplant tourism may give a patient access to a desperately needed organ, it may also place the patient in a perilous position. Patients receiving transplants in foreign countries take on the risks associated with having a surgical procedure in a jurisdiction not governed by the safety standards that apply in the United States. Thus, the patient may have higher risks of infection and of receiving an organ that is not a medically appropriate match.

While the natural instinct is to think of HHS's goal of maximum survival rates in terms of the recipient, it should also be thought of as the goal for living donors. This is not an issue when the donor is already deceased, but it is paramount in the case of a living donor who consents to donation of organs such as a kidney, partial lung, or bone marrow. According to Luc Noel of the World Health Organization's health and technology and pharmaceuticals unit, many of the people who sell their organs and tissues are not given proper follow-up medical care and their health risks increase, thus decreasing their potential for survival. ${ }^{167}$ Noel further explains that "[l]ive donations are not without risk, whether the organ is paid for or not. The donor must receive proper medical follow-up but this is often lacking when he or she is seen as a means to making a profit." 168

Those opposed to allowing patients to wait list themselves at multiple transplant centers may argue that "transplant tourism" is occurring right now while multiple listing is allowed. However, disallowing multiple wait listing may increase the likelihood that the wealthy will turn to this practice.

163. Laura MacInnis, "Transplant Tourism" On Rise Due to Donor Shortages, REUTERS HEALTH (Mar. 30, 2007), http://www.reuters.com/article/idUSL3042128920070330.

164. Id.

165. Id. ("The wealthy, in search of their own survival, will sometimes seek organs from the poor.").

166. Hearings, supra note 58, at 248.

167. MacInnis, supra note 163.

168. Press Release, World Health Organization, WHO Proposes Global Agenda on Transplantation, New World Observatory Launched with Spain (Mar. 30, 2007), available at http://www.who.int/mediacentre/news/releases/2007/pr12/en/index.html. 
In order to engage in transplant tourism, the patient must be healthy enough to travel to a foreign country for a transplant surgery. If a patient is healthy enough to travel to the other side of the world, it is unlikely that he or she would get a 1A status code or a high MELD score. Thus, he or she would be placed at the end of the waiting list and may have to wait a very long time before being offered a donor organ. In these cases, the transplant tourism option may seem particularly appealing if this patient lives in an area where the wait time for the needed organ is exceptionally long. While allowing multiple wait listing has not stopped the practice of transplant tourism, it at least offers a more attractive, and potentially safer option.

(III) Competition may generate improved processes and techniques

Transplant centers with higher survival rates are likely to be solicited more by those able to list at multiple centers and survival rates may improve accordingly. While NOTA protects against organ commoditization by prohibiting individuals from benefitting financially from organ donation, ${ }^{169}$ it permits OPOs and transplant centers to receive "reasonable payments associated with the removal, transportation, implantation, processing, preservation, quality control, and storage of a human organ." 170 Thus, the parties involved in harvesting, transporting, and transplanting the organ, as well as caring for the patient, stand to gain financially by performing these services. As a result, each party has incentive to provide the best services to the most people possible in order to gain the most payment possible. If a center is known to have particularly positive outcomes, it follows that patients who have the means to travel are more likely to list themselves at that center. This potential will incentivize centers to provide services rendering the best outcomes. When this occurs, it leads to efforts to improve the processes of procurement and transplantation. If patients were only allowed to list themselves at the transplant center in the area where they are domiciled, the incentive for the center to improve may be diminished because the patient does not have the option of seeking these services elsewhere and will settle for whatever services the local center provides.

\section{B. Arguments for Disallowing Patients to Place Themselves on Multiple Waitlists}

\section{Public View of the Fairness of the System Affects the Likelihood of Donation}

Organ harvesting can only occur if the patient or the appropriate family member gives consent. ${ }^{171}$ Those opposed to multiple wait listing may

170. 42 U.S.C.A. $\$ 274(\mathrm{e})(\mathrm{c})(2)$ (West 2003).

171. See generally McFall v. Shimp, 10 Pa. D. \& C.3d 90, 90 (Allegheny County 1978) (holding that a patient has the right to refuse unwanted bodily intrusion). See also Brother- 
argue that the number of people willing to make donations will decrease if people find that the organ transplant process unfairly benefits the wealthy. This argument would have more validity if the current system did not allow multiple listings and was being changed to do so. In such a situation, the change would gain public attention and could sour the public's view of the system. However, this system has been in place since $1984 .{ }^{172}$ Because the system is long-standing, the fact that multiple wait listing is allowed seems to gain attention only when well-known Americans undergo an organ transplant in an area far from their home. ${ }^{173}$

While it may be argued that this media attention highlights an aspect of the process that may influence potential donors to not donate their organs, the effect may actually be the opposite. While the attention may tend to focus on a potential inequality, it does not highlight any illegal activity by the actor because UNOS policies expressly allow multiple listings. ${ }^{174}$ While it initially focuses on the actions of the wealthy patient, attention may quickly turn to the large disparity between the number of organs donated and the number of patients in need waiting on the list. After learning of this disparity, it is entirely possible that people may be inspired to donate their organs or to be sure to make their wishes to be a donor known. Further, the current culture of the United States seems to be one that is very interested in the activities of the rich and famous. If a well-liked celebrity has a successful organ transplant, he or she may be more likely to become an organ donor, and in a culture that follows the lead of its celebrities, this may lead to many others doing the same.

\section{Allowing Multiple Listings "Pushes" a Truly Local Patient Down the List Further and Forces Him to Wait Longer}

Logically, any time that a patient awaiting a transplant is awarded an organ, every other person on that same list is forced to wait for the next possible match. While the preceding portions of this note have discussed the ability of a patient to decrease their waiting time by placing him or herself on multiple lists, no attention has been given to the patients that remain on the list once the patient listed at multiple centers receives an organ. For example, if UNOS did not allow listings in areas where a patient does not live, Steve Jobs (a California resident) would not have been able to place himself on the waitlist at the transplant center in Tennessee and a patient behind him on that list would have received that liver. While this is true,

ton v. Cleveland, 923 F.2d 477 (6th Cir. 1991) (aggregating property rights to create an entitlement interest in the body of the deceased and disallowing removal of corneal tissue without consent).

172. National Organ Transplant Act, Pub. L. No. 98-507, 98 Stat. 2339 (1984) (codified as amended at 42 U.S.C. $\$ 273-74(2006)$ ).

173. The attention that the transplant system gained after Steve Jobs' transplant is a perfect example of this. See Hainer, supra note 1.

174. UNOS 3.2, supra note 25. 
this difference is negated on a nationwide scale. After Jobs received his liver in Tennessee, UNOS policy required his removal from all other waitlists and patients on each of these lists moved one step closer to the life saving liver transplant that they had been desperately waiting for.

For further explanation, recall the aforementioned hypothetical considering Patient $\mathrm{X}$ and Patient $\mathrm{Y}$ who have the same blood type, need the same organ, and are given the same MELD score. ${ }^{175}$ Both patients are listed at Transplant Hospital 1, but Patient $\mathrm{X}$ was placed onto the wait list one day before Patient Y. Patient X is also listed at Transplant Hospitals 2, 3,4 , and 5. Patient $X$ receives a transplant at Transplant Hospital 2 and Patient $\mathrm{Y}$ benefits (as previously described). While this is clearly a potential benefit for Patient Y, Patient $Z$ listed at Transplant Hospital 2 has been bumped down the list because Patient $X$ has been listed ahead of him. Patient $Z$ has now effectively been placed one spot lower than if Patient $X$ was required to list himself only at his local transplant center. While this is true, Patient X will only receive an organ from one of the transplant centers where he was listed. In the current example, Patient $Z$ will actually only be affected twenty percent of the time that he and Patient $X$ have the same transplant criteria. More often, Patient $X$ will be removed from the list that Patient $\mathrm{Z}$ is on. Because UNOS requires Patient $\mathrm{X}$ to be removed from all other lists, ${ }^{176}$ no inefficiency will occur from Patient $\mathrm{X}$ remaining on lists after receiving his transplant. More importantly, Patient $X$ would not have listed himself at Transplant Hospitals 2-5 unless these facilities already had a low median wait time. The Transplant Hospital where Patient $\mathrm{X}$ receives his organ operates with an OPO which has proven that it was quickest at procuring a particular organ for that particular type of recipient and the wait at this center is still likely shorter than the national median wait time. While Patient $Z$ may have an increased wait list a small percentage of the time, the overall effect will likely be increased efficiency.

\section{CONCLUSION}

The National Organ Transplant Act of 1984 addressed Congress's concerns over the medical and ethical issues involved in the evolving field of organ transplantation. ${ }^{177}$ Congress wisely chose to leave decisions about the medical criteria involved in organ allocation and transplantation to medical professionals. ${ }^{178}$ In doing so, Congress left the decisions concerning organ procurement, transportation, allocation, and procedures to transplan-

175. See supra Part III.A.2.

176. UNOS, supra note 145.

177. S. REP. No. 98-382, at 2-4 (1984), reprinted in 1984 U.S.C.C.A.N. 3,975, 3978. See also 42 U.S.C. § 273-274 (2006).

178. 42 U.S.C.A. $\S 274(b)(2)$ (West 2003); Organ Procurement and Transplantation Network, 63 Fed. Reg. 16,296, 16,300 (Apr. 2, 1998) (to be codified at 42 C.F.R. Part 121). 
tation professionals and those on the board at UNOS. ${ }^{179}$ Currently, UNOS policies allow patients the option of placing themselves on multiple waitlists, in unlimited geographical areas. ${ }^{180}$ Recently, the fact that Steve Jobs received a liver transplant at a hospital located in Tennessee gained media attention and turned the public's attention to this potential inequity in UNOS's organ allocation policy. ${ }^{181}$ While some members of the public may then view the organ allocation process in a negative light, continuing to allow patients to list themselves at multiple transplant centers is the best of all potential options.

Patient autonomy is an important aspect of today's health care system. Patients are free to make decisions concerning which treatments they wish to participate in, and which ones they wish to forgo. Furthermore, patients are essentially free to decide which health care providers they consult, and from whom they receive treatment. Nowhere is this autonomy more important than in the situation where a patient's life is at stake, which is frequently the case for those seeking transplants. As previously discussed, ${ }^{182}$ OPOs functioning in different geographic regions procure organs at different rates. Therefore, patients on the waiting list of the transplant centers served by these OPOs have different median wait times before receiving the organ that they so desperately need. In addition, transplant centers have different procedures and surgical outcomes. If UNOS policies are changed to require patients to be wait-listed only at the transplant center nearest their home, these patients will be stripped of their autonomy at the time they likely have the most interest in making these decisions. If, instead, they are able to maintain their autonomy, patients are likely to choose the transplant center that gives them the best chance at survival. Because OPOs and transplant centers make a profit in the organ transplant process, the ability of patients to choose their transplant center will likely incentivize the OPOs and transplant centers to function at the most efficient and most cost effective manner possible.

Proponents of creating a new UNOS policy restricting multiple wait listing may argue that the current system, coupled with the current media attention that the policies are receiving, may cause the public to distrust the organ allocation system and dissuade them from becoming an organ donor. While this attention may decrease the likelihood of a small percentage of potential organ donors, it is not likely that this will have much impact on the number of organ donors. First, this UNOS policy has been in place for years. The mass attention given to this policy occurs only when the media covers a famous person who has used the system to his advantage (as in Steve Jobs' case). In a culture that is very interested in its celebrities and

179. See generally 42 U.S.C $\S 273-74$ (2006).

180. UNOS 3.2, supra note 25 .

181. Hainer, supra note 1.

182. See supra notes $128-132$ and accompanying text. 
often follows their lead, this media attention could actually cause the public to become more interested in organ donation.

While some may argue that the current system allows the wealthy to "push" those less fortunate out of line, multiple wait listing may actually benefit those who are only on a single list while only increasing the wait of these single listed patients a small percentage of the time. ${ }^{183}$ Multiple wait listing may also help achieve HHS's goal of minimal wasting of organs by decreasing cold ischemia time related to transporting an organ from donor to recipient. Additionally it helps ensure safety (while improving outcomes) by offering the most suitable match based on medical criteria while improving the ability to keep organs local to decrease the cold ischemia time. The current system also helps ensure the safety of those donating nonessential organs by decreasing the likelihood that the wealthy will turn to transplant tourism, ${ }^{184}$ thus decreasing the likelihood that the poor will become a "source of spare parts for the rich."

While it is likely true that the current UNOS policies allowing multiple wait listing may cause a small portion of the American public to view the organ transplant system in a negative light, the benefits that the system offers strongly outweigh the potential negative impact caused by media. Because of the strength of the arguments for keeping the current policies in effect, maintaining the status quo is clearly the best option.

183. See discussion supra at Parts III.A.2 and III.B.2.

184. See discussion supra Parts III.A.4.

185. Hearings, supra note 58, at 218. 